\title{
The Effect of Formalin Solution On Surgical Margin Distance and Tumor Size in Colonspecimens Resected Because of Sigmoid Colon Cancer
}

\author{
D Hüseyin Çiyiltepe, ${ }^{1}$ (1) Ebubekir Gündeş, ${ }^{2}$ (1) Durmuş Ali Çetin, ${ }^{3}$ (1) Ulaş Aday, ${ }^{4}$

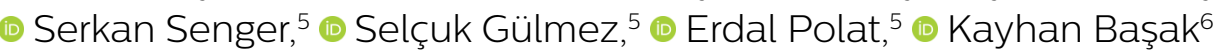

\author{
'Department of Gastroenterologica \\ Surgery, University of Health \\ Sciences, İstanbul Fatih Sultan \\ Mehmet Training and Research \\ Hospital, İstanbul, Turkey \\ 'Department of Gastroenterologica \\ Surgery, University of Health \\ Sciences, Diyarbakır Gazi Yaşargi \\ Training and Research Hospital, \\ Diyarbakır, Turkey \\ ${ }^{3}$ Department of Gastroenterological \\ Surgery, University of Health \\ Sciences, Şanlıurfa Training and \\ Research Hospital, Sanlıurfa, Turkey \\ ${ }^{4}$ Department of Gastroenterological \\ Surgery, University of Health \\ Sciences, Elazığ Training and Re- \\ search Hospital, Elazı̆̆, Turkey \\ ${ }^{5}$ Department of Gastroenterological \\ Surgery, University of Health \\ Sciences, İstanbul Kartal Koşuyolu \\ High Speciality Training and \\ Research Hospital, İstanbul, Turkey \\ ${ }^{6}$ Department of Pathology, \\ University of Health Sciences, \\ Kartal Dr. Lütfi Kırdar Training and \\ Research Hospital, İstanbul, Turkey
}

Submitted: 17.06.2020 Accepted: 11.08.2020

Correspondence: Hüseyin Çiyiltepe, SBÜ, İstanbul Fatih Sultan Mehmet Eğitim ve Araştırma Hastanesi, Gastroenteroloji Cerrahisi Kliniği, Istanbul, Turkey

E-mail: drciyiltepe@hotmail.com

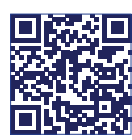

Keywords: Colon cancer; formalin fixation; shrinkage; surgical margin.

\section{(1) (1)}

\begin{abstract}
Objective: Formalin fixation results in decrease in the size of resection materials up to $57 \%$ in different tissues. The objective of this study was to determine the effects of formalin fixation on the longitudinal size and tumor size of resected colon tissue because of a sigmoid colon tumor.
\end{abstract}

Methods: This prospective study was conducted with 40 consecutive sigmoid colon tumor patients who underwent elective resection between January and December 2016. The surgeon conducting the study opened up the specimens within 15 minutes of resection, and the total length of the resected colon, size of the tumor, and proximal and distal surgical margin distances were then measured. The pathologist then recorded the measurements, without applying any stretch.

Results: The mean total length, proximal surgical margin distance, distal surgical margin distance, and size of the tumor in the resected material were $32.9 \mathrm{~cm}, 16.7 \mathrm{~cm}, 12.1 \mathrm{~cm}$, and $4.8 \mathrm{~cm}$, respectively. Postformalin fixation values were $22.0 \mathrm{~cm}, 10.6 \mathrm{~cm}, 7.4 \mathrm{~cm}$, and $4.2 \mathrm{~cm}$, respectively, in the same order $(p=0.00$ for all).

Conclusion: The results of the present study revealed $34 \%$ shrinkage in the total size of colon material following fixation. The effect of formalin fixation on shrinkage should be considered in cases where there is an unexpected proximity to surgical margins, as shown by the pathology results.

\section{INTRODUCTION}

Colorectal cancer (CRC) is the most common cancer of the gastrointestinal system and the second most common cause of mortality after breast cancer in females and lung cancer in males. ${ }^{[1]}$ Surgery is the treatment for CRC. The objective of surgical intervention is to achieve wide re- 
section of the affected intestinal segment together with lymphatic drainage. ${ }^{[2]}$

Various factors can affect postoperative local recurrence, with positive or close surgery that proves to be a significant cause of local recurrence at surgical margins. ${ }^{[3]}$ The distance between the tumor and surgical margins is a vital parameter in the evaluation of the sufficiency of surgical excision. ${ }^{[3]}$ It is stated in many guidelines that a negative surgical margin minimum of $5 \mathrm{~cm}$ from the proximal and distal should be achieved in sigmoid colon and proximal rectum tumors. ${ }^{[2,4]}$ Final pathology reports may reveal unexpected results pertaining to surgical margins, despite surgeons thinking that they have achieved the targeted surgical margin during surgery.

Formalin fixation results in decrease in the size of resection materials, with studies of different tissues reporting shrinkage rates between $4.6 \%$ and $57 \% .{ }^{[5-7]}$ The aim of this prospective study was to determine the effects of formalin fixation on the longitudinal size and tumor size of resected colon tissue because of a sigmoid colon tumor.

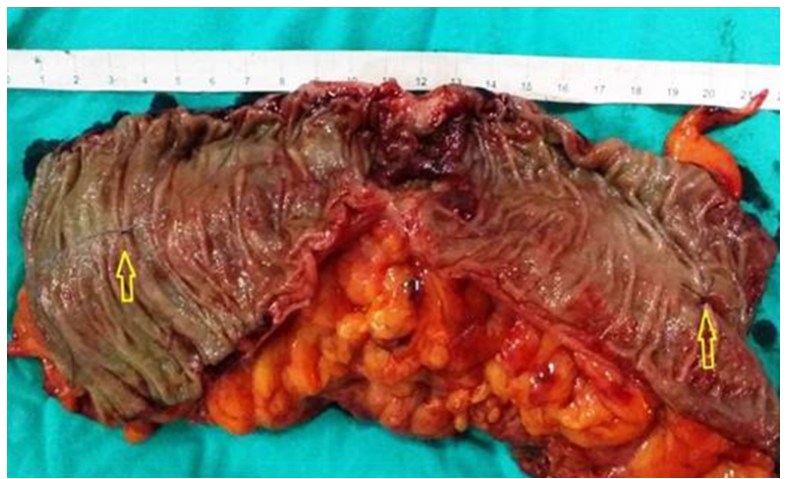

Figure 1. Sigmoid colon resection material (proximal and distal surgical margins were marked with silk suture, yellow arrows).

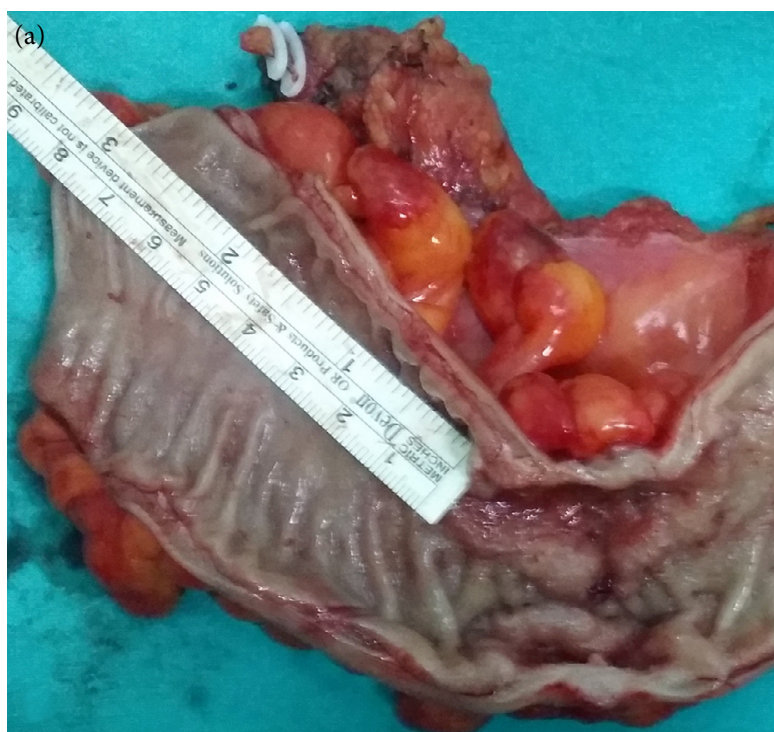

Figure 2. Measurements of fresh (a) and fixed (b) tissue.

\section{MATERIALS AND METHODS}

\section{Ethical declaration}

This study was planned as a prospective study pursuant to the consent of the board of ethics of Kartal Dr. Lütfi Kırdar Training and Research Hospital (No: 895 I3307/1009/507).

\section{Study population}

All patients who underwent surgery because of sigmoid colon cancer in Kartal Koşuyolu High Speciality Training and Research Hospital between January 2016 and December 2016 were included in the study.

\section{Inclusion criteria}

I. All patients who underwent surgery because of sigmoid colon cancer.

\section{Exclusion criterion:}

I. Patients not willing to participate in the study.

2. Patients who underwent colon resection for non-cancer causes.

3. Patients who underwent length measurement of surgical material after the first 15 minutes of resection.

\section{Study design}

Fresh colon specimens were resected from patients who received anterior resection because of a sigmoid colon tumor. The surgeon conducting the study opened up the specimens from the nontumor side within 15 minutes of resection if the tumor did not have circular involvement and from the antimesenteric side if circular involvement was present. The total length of the resected colon, size of the tumor, and proximal and distal surgical margin distances were then measured. Proximal and distal margins of 5 or $10 \mathrm{~cm}$ of the tumor was marked by a silk suture to

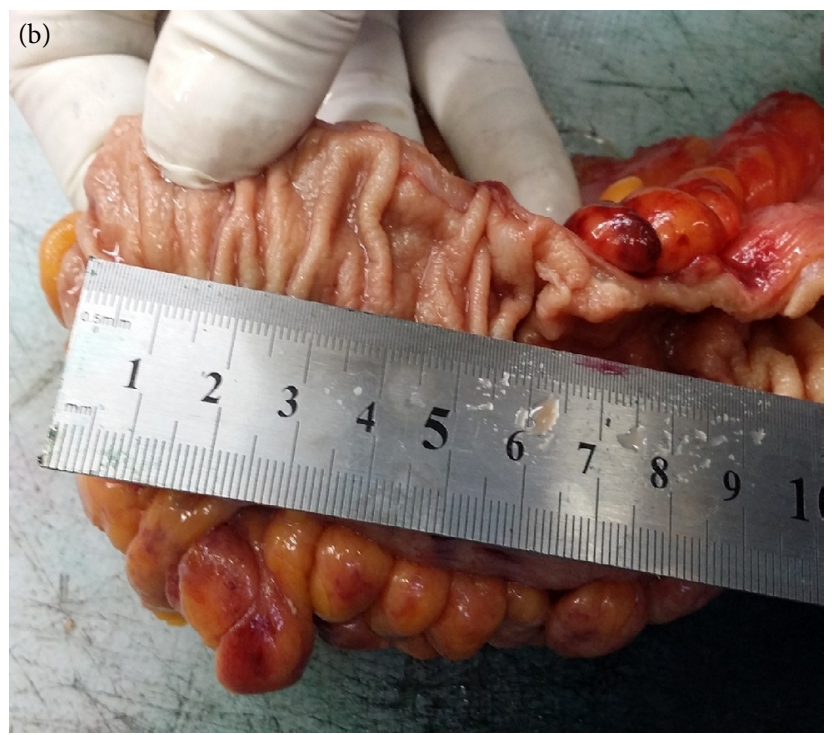


establish a measurement standard (Fig. I). The resection material was immersed in $10 \%$ formalin solution after suturing. The formalin-fixed tissue specimens were removed from the solution after $12-18$ hours by a pathologist. The pathologist then recorded the same measurements without applying any stretch (Fig. 2). Normal histopathological evaluation procedures were then undertaken.

Data

The measurements done by surgeon and pathologist, age, body mass index (BMI), type of operation (laparoscopic/ open method), and duration of immersion of the colon materials in formalin solution were recorded.

Primary endpoint of this study

The study explored the shrinkage effects of formalin both on normal colon tissue (by surgical margin measurements) and tumor size.

\section{Statistical analysis}

Statistical analyses were conducted using the Statistical Package for the Social Sciences, version 2 I (SPSS Inc., Chicago, IL, USA). The recorded data were presented as mean
( \pm standard deviation [SD]) and minimum and maximum. The resected colon material and fixed colon material measurements were compared using a paired t-test.

\section{RESULTS}

In total, 40 patients were included in the study who underwent surgery because of sigmoid colon cancer in Kartal Koşuyolu High Speciality Training and Research Hospital between January 2016 and December 2016. Seventeen (42.5\%) of the patients were female and 23 (57.5\%) were male. Their mean age was $62.4(35-80)$ years, and the mean BMI was $27.6 \mathrm{~kg} / \mathrm{m}^{2}\left(22-36 \mathrm{~kg} / \mathrm{m}^{2}\right)$. In this study, $28(70 \%)$ patients had anterior resection by the open method, and 12 (30\%) patients had laparoscopic anterior resection.

The mean total length, proximal and distal surgical margin distance, and size of the tumor in the freshly resected material were $32.9 \mathrm{~cm}, 16.7 \mathrm{~cm}, 12.1 \mathrm{~cm}$, and $4.8 \mathrm{~cm}$, respectively. Postformalin fixation values were $22.0 \mathrm{~cm}, 10.6$ $\mathrm{cm}, 7.4 \mathrm{~cm}$, and $4.2 \mathrm{~cm}$, respectively (Table I). There were statistically significant differences in all the measurements of fresh and fixed tissues ( $p=0.00$ for all) (Table 2 ).

Table I. Measurements of fresh and fixed tissue

\begin{tabular}{lcccc}
\hline & Mean & Standard deviation & Minimum & Maximum \\
\hline Age $($ years) & 62.40 & 11.57 & 35.00 & 84.00 \\
BMI $\left(\mathrm{kg} / \mathrm{m}^{2}\right)$ & 27.60 & 3.22 & 22.00 & 36.00 \\
Total lenght of resected colon-Fresh $(\mathrm{cm})$ & 32.95 & 7.01 & 19.00 & 53.00 \\
Total lenght of resected colon-Fixed $(\mathrm{cm})$ & 22.06 & 5.61 & 11.00 & 39.00 \\
Proximal surgical margin lenght-Fresh $(\mathrm{cm})$ & 16.78 & 4.623 & 9.00 & 32.00 \\
Proximal surgical margin lenght-Fixed $(\mathrm{cm}$ & 10.69 & 0.42 & 5.00 & 22.00 \\
Distal surgical margin lenght-Fresh $(\mathrm{cm})$ & 12.10 & 3.52 & 7.00 & 18.00 \\
Distal surgical margin lenght-Fixed $(\mathrm{cm})$ & 7.40 & 2.94 & 3.00 & 12.00 \\
Tumor size - Fresh $(\mathrm{cm})$ & 4.82 & 1.54 & 2.00 & 8.00 \\
Tumor size - Fixed $(\mathrm{cm})$ & 4.27 & 1.45 & 2.00 & 7.50 \\
\hline
\end{tabular}

Kg: Kilogram; m: Meter; cm: Centimeter.

Table 2. Differences between fresh and fixed tissue measurements

\begin{tabular}{|c|c|c|c|c|c|c|}
\hline & \multicolumn{5}{|c|}{ Paired differences } & \multirow[t]{3}{*}{ p value } \\
\hline & \multirow[t]{2}{*}{ Mean } & \multirow[t]{2}{*}{ Std. deviation } & \multirow[t]{2}{*}{ Std. Error Mean } & \multicolumn{2}{|c|}{$95 \% \mathrm{Cl}$ of the difference } & \\
\hline & & & & Lower & Upper & \\
\hline Total lenght & 10.89 & 2.35 & 0.37 & 10.14 & 11.64 & 0.00 \\
\hline Proximal surgical margin lenght & 6.09 & 1.86 & 0.29 & 5.49 & 6.69 & 0.00 \\
\hline Proximal surgical margin lenght & 4.71 & 1.19 & 0.19 & 4.32 & 5.09 & 0.00 \\
\hline Tumor size & 0.55 & 0.38 & 0.06 & 0.43 & 0.67 & 0.00 \\
\hline
\end{tabular}


There was a $34.3 \%, 38.4 \%, 40.1 \%$, and $12.4 \%$ decrease in the total length, proximal and distal surgical margin distance, and tumor size of the fixed tissues, respectively as compared to the fresh tissues. There was a $37.6 \%$ decrease in the proximal surgical margin distance and $41.8 \%$ decrease in the distal surgical margin distance marked by the silk suture (used to achieve standardization). These measurements were correlated with measured surgical margin distances.

\section{DISCUSSION}

This prospective study examined the shrinkage effect of formalin on normal colon tissue by the measurements of surgical margins and tumor size. The effects of formalin fixation on tissue samples occur in two ways: First, the formalin solution rapidly saturates into tissue by diffusion. Formalin exerts a gelling effect after increasing to a particular concentration that results in the formation of wide crosslinks among proteins or between proteins and nucleic acids. Thus, it stabilizes the tissue infrastructure. Second, formalin fixation sometimes causes tissue damage, in addition to vacuolization, and cell shrinkage. ${ }^{[8]}$ These formalin fixation-induced effects influence immunohistochemical reactivity and may give rise to sizable alterations in shapes and sizes of tissue samples. ${ }^{[9]}$

Some studies demonstrated the effects of formalin fixation on tissue size accounted for conflicts between surgeons and pathologists. One study reported that the tumor sizes were greater during surgery or prior to formalin fixation, especially in tumors where the $T$ stage was related to tumor size. ${ }^{[10]}$ In a study of 40 I patients with non-small cell lung cancer, formalin fixation caused sizable alterations in the sizes of tumors and resulted in downstaging ( $\mathrm{Tl}$ instead of $\mathrm{T} 2$ ) of tumors in the $\mathrm{T}$ stage. ${ }^{[10]}$ In another study of 34 patients with renal tumors, the sizes of fresh tumors shrank by $12.1 \%$ after formalin fixation, as shown by a radiological evaluation. ${ }^{[5]}$ The same study reported that the tumor size decreased even more (i.e., by $4.6 \%$ ) after formalin fixation. ${ }^{[5]} \mathrm{A}$ study of the effects of formalin fixation on tumor surgical margins in patients with breast cancer reported mean shrinkage in the surgical margin of about $2.14 \mathrm{~cm}$, and the authors concluded that this shrinkage had implications for postoperational management. ${ }^{[6]}$ Measurements of sigmoid and rectal resection materials obtained from 26 patients who had undergone surgery for various reasons revealed $57 \%$ shrinkage in the size of the resection materials after formalin fixation. ${ }^{[7]}$ In the study $70 \%$ of the shrinkage took place between in vitro measurements and the time of obtaining freshly resected tissue, underlining the role of formalin fixation in inducing shrinkage (30\%). ${ }^{[7]}$

No previous studies had examined the effect of formalin fixation on tumor measurements in patients with sigmoid colon cancer. This study designed prospectively with an isolated group of patients with sigmoid colon tumor proved to be significant in this sense. Limited number of cases and lack of in vitro measurements were the limitations of the study.

This study of 40 patients with sigmoid colon tumor revealed a $34.3 \%$ decrease in total length, $38.4 \%$ decrease in proximal surgical margin distance, $40.1 \%$ in distal surgical margin distance, and $12.4 \%$ in tumor size in fresh versus fixed issues. This contraction effect of formalin should be considered especially in cases that we have achieved a negative surgical margin during surgery, but the surgical proximity/positivity is the result of the final pathology. We believe that surgical margin measurements of fresh tissues or fixed tissues are more valuable in patient management, particularly in cases of distal rectal cancer, where surgical margin negativity is sufficient, but excision of broader surgical margins in order to protect the sphincters is not possible.

The results of the present study revealed a $34 \%$ shrinkage in the total size of colon material following fixation. The effect of formalin fixation on shrinkage should be considered in cases where there is unexpected proximity to surgical margins, as shown by the final pathology results.

\section{Ethics Committee Approval}

Approved by the Kartal Dr. Lütfi Kırdar Training and Research Hospital ethics committee (no: 895/3307/ 1009/507).

\section{Peer-review}

Internally peer-reviewed.

Authorship Contributions

Concept: H.Ç., U.A., K.B.; Design: H.Ç., E.P., K.B.; Supervision: E.P., S.G., S.S.; Materials: E.G., D.A.Ç., H.Ç.; Data: S.G., S.S., K.B.; Analysis: E.P., E.G., D.A.Ç.; Literature search: E.G., D.A.Ç., U.A.; Writing: H.Ç., U.A., K.B.; Critical revision: S.S., S.G., E.P.

Conflict of Interest

None declared.

\section{REFERENCES}

1. Ferlay J, Soerjomataram I, Dikshit R, Eser S, Mathers C, Rebelo M, et al. Cancer incidence and mortality worldwide: sources, methods and major patterns in GLOBOCAN 2012. International journal of cancer 2012;136:E359-86

2. Nelson H, Petrelli N, Carlin A, Couture J, Fleshman J, Guillem J, et al. Guidelines 2000 for colon and rectal cancer surgery. Journal of the National Cancer Institute 2001;93.8:583-96.

3. Sugarbaker PH. Update on the prevention of local recurrence and peritoneal metastases in patients with colorectal cancer. World Journal of Gastroenterology 2014;20.28:9286-91.

4. Labianca R, Nordlinger B, Beretta GD, Mosconi S, Mandala M, Cervantes A, et al. Early colon cancer: ESMO Clinical Practice Guidelines for diagnosis, treatment and follow-up. Annals of oncology 2013;24:64-72.

5. Tran T, Sundaram CP, Bahler CD, Eble JN, Grignon DJ, Monn MF, et al. Correcting the shrinkage effects of formalin fixation and tissue processing for renal tumors: toward standardization of pathological reporting of tumor size. Journal of Cancer 2015;6:759-66.

6. Zaidi M, Khan S, Farooqi NB, Abbas K, Idrees R. Effect of formalin fixation on surgical margins in breast cancer surgical specimen. Int J Breast Cancer 2014;2014:121838. 
7. Goldstein NS, Soman A, Sacksner J. Disparate surgical margin lengths of colorectal resection specimens between in vivo and in vitro measurements: the effects of surgical resection and formalin fixation on organ shrinkage. American journal of clinical pathology 1999;111:349-51.

8. Prento P, Lyon H. Commercial formalin substitutes for histolopathology. Biotech Histochem 1997;72:273-82.
9. Werner M, Chott A, Fabiano A, Battifora H. Effect of formalin tissue fixation and processing on immunohistochemistry. Am J Surg Pathol 2000;24:1016-9.

10. Hsu PK, Huang HC, Hsieh CC, Hsu HS, Wu YC, Huang MH, et al. Effect of formalin fixation on tumor size determination in stage I non-small cell lung cancer. The Annals of thoracic surgery 2007;84:1825-9.

\section{Sigmoid Kolon Kanseri Nedeniyle Rezeksiyon Yapılan Kolon Spesmenlerinde Formalin Solüsyonun Cerrahi Sınır Uzaklığına ve Tümör Boyutuna Etkisi}

Amaç: Formalin fiksasyonu, farklı dokularda rezeksiyon materyallerinin boyutunda \%57’ye kadar azalmaya neden olur. Bu çalışmanın amacı, sigmoid kolon tümörü nedeniyle anterior rezeksiyon yapılan hastalarda formalin fiksasyonunun rezeke edilen kolon dokusunun boyuna, cerrahi sınır uzaklığına ve tümör boyutuna olan etkilerini belirlemektir.

Gereç ve Yöntem: Bu ileriye yönelik çalışma, Ocak ve Aralık 2016 tarihleri arasında elektif rezeksiyon uygulanan 40 ardışık sigmoid kolon tümörü spesmeni ile yapıldı. Çalışmayı yürüten cerrah tarafından çıkarılan spesmen üzerinde ilk 15 dakikada kolonun toplam uzunluğu, tümörün boyutu ve proksimal ve distal cerrahi sınır mesafeleri ölçüldü. Daha sonra spesmen \%।O'luk formalin ile fikse edildi ve aynı ölçümler fiksasyon soonrasında araştırmayı yürüten patolog tarafından yapıldı.

Bulgular: Yeni rezeke edilen materyaldeki ortalama toplam uzunluk, proksimal cerrahi sınır mesafesi, distal cerrahi sınır mesafesi ve tümörün boyutu sırasıyla $32.9 \mathrm{~cm}, 16.7 \mathrm{~cm}, 12.1 \mathrm{~cm}$ ve $4.8 \mathrm{~cm}$ idi. Postformalin fiksasyon değerleri sırasıyla $22.0 \mathrm{~cm}, 10.6 \mathrm{~cm}, 7.4 \mathrm{~cm}$ ve $4.2 \mathrm{~cm}$ idi (tüm değerler için $\mathrm{p}=0.00$ ).

Sonuç: Bu çalışmanın sonuçları, fiksasyonu takiben kolon materyalinin toplam boyutunda ortalama \%34 küçülme olduğunu ortaya koymuştur. Final patoloji sonuçlarında cerrahi sınırlara beklenmedik yakınlı̆̆ın olduğu durumlarda formalin fiksasyonunun küçülme üzerindeki etkisi dikkate alınmalıdır.

Anahtar Sözcükler: Büzülme; cerrahi sınır; formalin fiksasyon; kolon kanser. 